\title{
The Impact of Participatory Governance on Regional Development Pathways: Citizen-driven Smart, Green and Inclusive Urbanism in the Brainport Metropolitan Region
}

\author{
Christiane Gebhardt \\ Malik International, St. Gallen, Switzerland \\ christiane.gebhardt@t-online.de
}

\begin{abstract}
Urban innovation policies reintroduce the role of social entrepreneurs and civil society into innovation studies with regard to the governance of regional innovation and the emergence of new innovation pathways. The research approach integrates the concepts of urban and regional transformation, participatory governance and works with an actor-centered approach that employs the enactment of innovation models by actor constellations such as the smart city concept and the Triple Helix model. We illustrate the pathway of a citizen-driven approach in innovation for the case of Brainport smart district in the city of Helmond, in the metropolitan high-tech region Eindhoven in The Netherlands. The empirical data is obtained in a real-world laboratory (RWL) in a multi-stakeholder co-creation process. The case contributes to the categorization of citizen-driven innovation pathways within an extended approach of Economic Evolutionary Geography (EEG) and thus to the frame of reference for structural dynamics in social theory.
\end{abstract}

\section{Keywords}

smart sustainable cities - Brainport - social entrepreneurs - participatory governance - urban and regional innovation - innovation pathways 


\section{Arabic}

تأثير الحوكمة التشاركية على مسارات التنمية الإقليمية :التخطيط الذكي والأخضر والشامل في منطقة

برانبورت

تعيد سياسات الابتكار الحضري تثمين دور منظمي المشاريع الاجتماعيين والمجتمع المدني في دراسات الابتكار المتعلقة بإدارة الابتكار

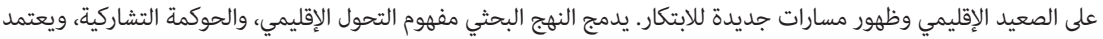

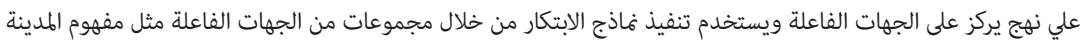

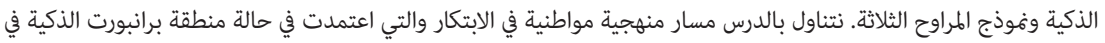

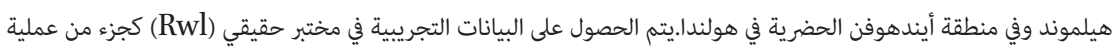

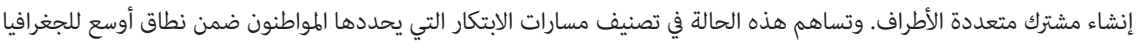

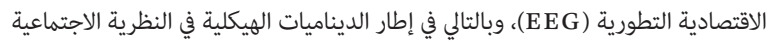

الكلمات المفتاح : مدن ذكية مستدامة، مختبرات، منظمي مشاريع اجتماعيين، إدارة تشاركية، ابتكار حضري وإقليمي، تحويل، مختبر من الواقع الحياتي، ومسارات إقليمية .

\section{Chinese}

\section{参与式治理对区域发展路径的影响：智慧港都市 区市民驱动的智慧、绿色和包容的城市规划}

\section{摘要}

城区创新政策将社会企业家和公民社会的作用重新纳入区域创新治理和新 创新路径出现的创新研究中。本研究的思路及技术路线整合了区域转型、 参与式治理的概念, 并结合以行动者为中心的方法路径, 即采用行动者星 座的创新模式, 如智慧城市概念和三螺旋模型。我们以荷兰埃因霍温大都 会区赫尔蒙德的智慧港都市区为例说明创新的公民驱动途径。实证数据是 在一个现实世界实验室 ( RWL) 在多方利益相矢者共同创造过程中获得的。 该案例有助于在经济进化地理学 (EEG) 的扩展途径中对公民驱动的创新路 径进行分类, 从而为社会理论中的结构动力学提供参考框架。 
智慧可持续城市、智慧港、社会企业家、参与式治理、城区和区域创新、 转型、现实世界实验室、区域路径

\title{
French
}

\section{L'impact de la gouvernance participative sur les voies de développement régional dans la région métropolitaine de Brainport: un urbanisme intelligent, vert et inclusif}

\author{
Christiane Gebhardt
}

\section{Résumé}

Les politiques d'innovation urbaine réintroduisent le rôle des entrepreneurs sociaux et de la société civile dans les études sur l'innovation notamment la gouvernance de l'innovation régionale et l'émergence de nouvelles voies d'innovation. La démarche de recherche intègre le concept de transformation régionale, de gouvernance participative et s'appuie sur une approche centrée sur les acteurs qui utilise la mise en place de modèles d'innovation par constellations d'acteurs, tels que le concept de ville intelligente et le modèle de la triple hélice. Nous illustrons le cheminement d'une approche axée sur les citoyens en matière d'innovation dans le district de Brainport Smart à Helmond, dans la région métropolitaine d'Eindhoven aux Pays-Bas. Les données empiriques sont obtenues dans un laboratoire du monde réel dans le cadre d'un processus de co-création multipartite. L'étude contribue à la catégorisation des voies d'innovation pilotées par les citoyens dans le cadre d'une approche élargie de la géographie de l'évolution économique et, partant, au cadre de référence des dynamiques structurelles de la théorie sociale.

\section{Mots clés}

Villes intelligentes et durables - Brainport - entrepreneurs sociaux - gouvernance participative 


\title{
Russian
}

\section{Влияние репрезентативного управления на региональные пути развития управляемого игражданами умного, зеленого и инклюзивного урбанизма в городском округе Брейнпорт}

\author{
Кристиан Гебхардт
}

\begin{abstract}
Аннотация
Городские инновационные стратегии возрождают интерес к социальному предпринимательству и роли гражданского общества в инновационных исследованиях, учитывая подходы к управлению региональными инновациями и появление новых инновационных моделей. В настоящем исследовании объединены концепции региональной трансформации, репрезентативного управления и подходов, основанных на центральной роли актора, который осуществляет внедрение инноваций совместно с несколькими участниками в рамках концепций «умный город» и «тройная спираль». Мы проиллюстрировали реализацию модели гражданского управления в сфере инноваций на примерах Умного города Брейнпорт в Хельмонде, Городского округа в Эйнховене в Нидерландах. Эмпирические данные были получены в лаборатории реального времени (RWL) в результате коллегиального творческого процесса. Пример позволяет категоризировать гражданские инновационные стратегии в рамках расширенной концепции Эволюционной экономической географии (EEG), тем самым модель отражает структурную динамику социальной теории.
\end{abstract}

\section{Ключевые слова}

Умные устойчивые города - Брейнпорт - социальные предприниматели репрезентативное управление - городские инновации 


\section{Spanish}

\section{El impacto de la gobernanza participativa sobre el desarrollo regional}

Un urbanismo participativo, inteligente, verde e inclusivo en la región metropolitana de Brainport

\section{Resumen}

Las políticas de innovación urbana pueden reintroducir el papel de los emprendedores sociales y la sociedad civil en la gobernanza del desarrollo regional. Mi argumento en este artículo se encuentra en la intersección de los estudios sobre transformación regional, gobernanza participativa, y la teoría actor-red. Busco aquí iluminar el proceso de promulgación de modelos de innovación como Ciudades Inteligentes y la Triple Hélice como una vía hacia la innovación urbana y el desarrollo regional participativo. Mi asidero empírico es un "laboratorio del mundo real" pués elaboro aquí un estudio de caso de Brainport Smart District-Helmond, en la región metropolitana de Eindhoven en Holanda. Espero con este artículo contribuir al campo de la Geografía Evolutiva Económica.

\section{Palabras clave}

Ciudad Sostenible e Inteligente - Brainport - emprendedores sociales - gobernanza participativa - innovación urbana

Never doubt that a small group of thoughtful, committed citizens can change the world; indeed, it's the only thing that ever has. (Margaret Mead)

\section{Introduction}

In recent years the smart city has emerged in the urban and regional context and cities have become the key locations for the implementation of data driven high-tech solutions and infrastructural innovations in order to implement climate policies that aim at resource efficiency, air quality improvements and sustainable building solutions. However, in fast-growing high-tech regions, 
where a too-narrow focus on science and technology has led to unintended consequences that deteriorate wellbeing and liveability in terms of affordable housing, social inclusion and to ecological soundness, there is a growing resistance from citizens in regard to these costly and technology driven changes (Etzkowitz 2013; Etzkowitz and Steiber 2019; Shi et al. 2016; Martinez-Alier et al. 2014; Lowe and Wolf-Powers 2018 on inclusive innovation). Evidently, providing smart, green and inclusive urbanism is one of the great conundrums of our time and qualifies for the category of wicked problems (Hardin 1968; Conklin 2005; Bueren et al. 2003; Head 2008; Head and Alford 2015; Roberts 2000). Increasingly the reconciliation of opposites of climate policy and affordable housing in smart cities has become a topic that incites citizen to engage in an old debate on the societal value of science and high technology, and to question the governance of technology and science for so called smart city solutions (Hohn and Schimank 199o; Kuhlmann and Shapira 2006).

On a theoretical level citizen directed innovation and multi-stakeholder actor constellations are relatively new phenomena in research and science driven urban development and might change our comprehension of structural dynamics in social theory. As innovation studies extends its focus from mapping institutional settings to urban and regional transition, and from technological to social innovation, the role of individuals and civil society is brought to the forefront of attention and social entrepreneurship becomes a launch pad for future innovation pathways.

Beyond innovation policies and entrepreneurial strategies, the frequently asked question is, who shall assume governance in the process of urban and regional innovation and what kind of multi-scalar arrangements are suitable and legitimate to develop a sustainable development path? (Hansen and Coenen 2015; Raven et al. 2012, Geels 2002) What kind of institutional organisation and transformative and adaptive governance must coevolve with emerging topics for an on-going co-creation process (Gong and Hassink 2017; Folke et al. 2005) and what roles do innovation models, norms, shared belief systems and the history of places (Weick 1979; Grandori 1997) play for path creation and for the coherence of new arrangements?

To operationalize the questions above we run a case study for Brainport Smart District (BSD) in Helmond city in the metropolitan science region Eindhoven. Research data was collected in a semi-controlled real-world laboratory in a multi-stakeholder co-creation process in the period of November 2016 to March 2017. The explanatory research follows a new transformative exploration approach of real-world laboratories (RWL) (Wanner et al. 2018) in which representatives from science, industry, government and civil society cooperate for a common understanding about current challenges and develop robust solutions (Schneidewind 2014) with a learning methodology facilitating solution 
oriented system and with a communication architecture called syntegration ${ }^{\circ 1}$ (Mieg and Grafe 2012). The lab design sets a focus on the phase where a structured co-creation communication architecture allows a social entrepreneur to invite actors from different societal spheres to form a temporary collective action and reflect urban tradition and identity, relevant innovation models and societal norms in order to define priorities of action, build collective rules for cooperation, implementation and transformation for a collectively accepted governance and for future urban development. The data collected in that setting increases our understanding of the possible expressions of participatory, transformative governance and shows effects on the institutionalization patterns of innovation, and the formation of urban and regional innovation pathways.

The structure of the paper is as follows. We discuss the relevant literature to define the role of social entrepreneurs in the transformation process, explain the importance of history of place and display the importance of innovation models for the recruitment of actors in regional and urban innovation. We explore relevant concepts for the frame of reference of the analysis.

In the research design section, we explain the extended real-world laboratory approach and the syntegration ${ }^{\circ}$ process. We introduce the methodical steps of a semi-controlled living laboratory in the urban context.

In the discussion we summarize the findings of the case study; and we suggest a tentative model for participatory and transformative governance that supports an evolutionary innovation pathway which is juxtaposed to a disruptive pathway.

The paper concludes with policy advice regarding the prospects of participatory governance in transforming cities and regions. We illuminate the crucial role played by public administration in urban transformation. Opportunities for further research are also outlined.

\section{Literature Review}

The framework for smart sustainable urban development and transition of innovation systems addresses an interdisciplinary field of literature in innovation studies.

The integration of approaches of regional innovation systems (Cooke and Leydesdorff 2006; Martin 2013; Martin and Sunley 2006; Gebhardt 1997, 2013), regional industrial evolution and regional transformation (for industry led

1 Protected by copyright and registered by Malik. 
transformation: Boschma 2017; Boschma et al. 2017; knowledge based: Martin and Trippl, 2017) and organizational development of multi-actor networking constellations (Sydow 1992; Baecker 1999; Granovetter 1985, 1977; Gebhardt and Pohlmann 2013) allow for a dynamic perspective in regional innovation studies within an extended paradigm of Evolutionary Economic Geography, or EEG (Hassink et al. 2018; Boschma and Frenken, 2018). Accordingly, Cohen and Levinthal (1990) as well as Daellenbach and Davenport (2013) make a reference to the dynamics of regional development when they discuss the importance of absorptiveness for regional and institutional innovation and the importance of learning and identity building for the organization of urban and regional development (Paasi 2003). Equally, Ritali, Agouridas, Assimakopoulos and Gies examine capture mechanisms in innovation ecosystems and show different pathways and institutionalization processes in their comparative case study (Ritala et al. 2013).

In Europe, regional paths of development are currently disrupted by a predominant digital and sustainable programmatic design in relation to the implementation of $\mathrm{SDG}^{2}$ and by policies of smart specialization (Foray et al. 2011) that postulate strategy driven development so that "future shapes regional transformation" (Hassink et al. 2018). Equally, Feldman and Lowe discuss policy driven development and collective action in places (Feldman and Lowe 2018). Madsen and Hansen distinguish between "effects of experiments in achieving actual sustainability gains ('goal-oriented objectives') and instigating broader institutional change ('process-oriented objectives')" in their study on implementation of climate policies in the urban context (Madsen and Hansen 2019). Furthermore, there are non-intended effects of smart city growth such as unaffordable housing and health problems, urban sprawl and different living conditions in city centers and in the peripheries of cities, which increase pollution problems caused by commuters (Mieg and Töpfer 2013; Mora et al 2017).

At the same time, discussions about participatory governance (Baasch and Blöbaum 2017; Walk 2008; Fischer 2012) and the role of civil society in decisionmaking (Lovan et al. 2017) have drawn attention to the limits of a narrow institutional approach, focused on technological innovation, and its consequences in suppressing attention to regional, urban and social innovation. The technology bias that had been built into the fabric of innovation policy and innovation programs has obscured the fact that "social movements are widely recognized as drivers of social change and transformation" (Giddens 1990) and must not be seen as opposed to science driven governance regimes. It was not until

2 See: https://www.un.org/sustainabledevelopment/sustainable-development-goals. Accessed 6 August 2019. 
recently that social entrepreneurs were rediscovered by policy makers, industry, and in relation to innovation (Lundstrom et al 2014; Osburg and Schmidpeter 2013; Kanter 1998; Barendsen and Gardner 2004). However, there is no single type of social entrepreneur. For our research we follow Lights's definition of a "risk taking individual who creates social change against odds" (Light 2006) or that of Certo and Miller who define the social entrepreneur as somebody who "develops solutions for pressing social problems" (Certo and Miller 2008).

Other authors discuss the innovation process emerging from value-based innovation (Chell 2007) and there is a renewed interest in the regional effects of value-driven innovation (Chell et al. 2010) that relates to the debate of local participation in urban and regional development (MacCallum 2009; Anguelovski and Carmin 2011 on innovation and institutionalisation mechanisms in regard to high level concepts of climate policies). In this context the consideration of urban planning processes and the organisation of decision-making in public administration and city councils play an important role (Brandsen et al. 2016; Perrini et al. 2010; Urbano et al. 2010; Neumeier 2012; Kibert 2016). Therkildsen, Hansen, and Lorentzen show how an integrated implementation of climate policies encompasses social innovation and leads to experimentalism with participatory governance in the urban context (Therkildsen et al. 2009; Dawson and Daniel 2010). Consequently, the problem of governance for sustainability transitions (Engel and Knieling 2017) and the impact of participatory governance on regional path dependency in urban development (Moulaert et al. 2007) are discussed in that way that participatory governance is a social innovation per se and can increase the chance of "niche" developments or so called "incubation rooms" to become new "socio-economic regimes" (standards, techniques, rules, law) (Geels 2002; Geels and Schot 2007).

However, environmental movements have been more concerned with halting the developments of technologies found to be harmful and risky, or revising technologies in order to reduce, if not eliminate, their negative effects on health, wellbeing and the environment (Etzkowitz 1985 and 2015 on social movements; Florida et al. 2013; Dalziel and Saunders 2014 on wellbeing and happiness). Indeed, social movement, environmentalism, and high technology research have largely proceeded on different tracks, even when environmental regulation introduced as a result of social movements has been shown to be a significant driver of technological innovation in clean and solar technologies and urban development (Etzkowitz 1987). Equally, data analytics and artificial intelligence in planning systems, for example in relation to resource efficiency and cradle-to-cradle concepts in circular economy models, and in sectors such as mobility, energy, sustainable building and water management is frequently 
discussed as the smart side of green development in cities, but criticised in terms of ownership of data and inclusive development (Viitanen and Kingston 2014; Gebhardt 2017).

Presently, cities and metropolitan regions increasingly encourage and employ participatory and systemic approaches to solve these conflicts, implement innovation programs, and to address the concert of technological, environmental and social challenges with democratic principles and new integrated solutions (see real world laboratories/ RWL in Schneidewind 2014). However, the implementation of policies is sluggish and outcomes of these activities are diverse. The living labs employed in the urban context engage a large number of citizens in brainstorming processes but do not facilitate implementation.

In this line of reasoning, Isabel Dedring, the Deputy Mayor of London claimed in her speech at an urban age conference, held at the London School of Economics in 2012, that "long term mobilizing of citizens in innovation remains a problem because of the complexity deriving from a multitude of interests and values, the dissipative tendency, and the institutional blockage that a participation of citizen is constantly facing" (Sassen 2003; see also Sennet 2012; Fadaee and Schindler 2014; Braun et al. 2013 for citizenship behaviour; on the occupy movement: Chomsky 2012; and on traditional participation models: Florin 1990). Similarly, meaningful citizen engagement in science and technology is difficult and linked more to opposition and resistance. Equally, science organizations find it hard "to engage in engagement" (Powell and Colin 2008) and to deal with laypeople and amateurs.

Unfortunately, citizens very often lack managerial competence, expert scientific knowledge, the financial resources and the methods needed to link local development to technological innovation and bridge the institutional divides of university, industry and government relationships (Kaufmann and Toedtling 2001). As a result, these citizen engagements lack the eligibility for financial funding in innovation programs while initiatives of high technology consortia and legal entities qualify for public tenders and long-term funding, or even become attractive for private investors and venture capitalists. The latter, however, favour concepts that are focussed on corporate (and not regional) strategies and on science-based innovation. They rely on the economic capital rather than the social, and favour technical solutions that aim at rapid

3 Sennet R (2012) The Guardian. 'Nobody likes a city that is too smart'. Available at: https:// www.theguardian.com/commentisfree/2012/dec/04/smart-city-rio-songdo-masdar. Accessed 6 August 2019 . 
capitalization rather than social innovations. It seems that institutionalization and the organization of collectivism enables access to sustainable (long term) funding and that actors from industry and science are either more experienced in managing innovation than citizens or that such experience is attributed to them.

Although political awareness increases, such that both citizen engagement and the employment of mobilization techniques are necessary for socially accepted technical solutions, there is room for research on how individual players act in these settings, how collectivism materializes, and urban and regional innovation pathways emerge or diversify to the good or the bad of urban destinies in an enlarged regional perspective of cities and metropolitan regions.

\section{Theoretical framing: the actor-centered approach: from social entrepreneur to collectivism}

The integration of an actor-centered approach (Scharpf 2018) into the debate on evolutionary economic geography (Hassink et al. 2018) and regional innovation systems (Cooke and Leydesdorff 2006) underlines the inter-relationship of individuals who become connected by norms, shared history and collective beliefs in the process of organization (Weick 1995, Ostrom 2000). This perspective helps in developing an understanding of how social entrepreneurs use concepts and narratives such as the Triple Helix model of innovation and entrepreneurship, i.e. the intertwining of university, industry and government to build an urban system with a citizen-driven governance of science and therefore a new or modernised development path (Etzkowitz and Leydesdorff 2000; Etzkowitz 2008 for the Triple Helix in action; Leydesdorff and Deakin 2013 on the Triple Helix as a neo-evolutionary concept for smart cities; Carayannis and Campell 2010 for the quadruple helix approach). Therefore, the actor-centered approach is an essential additional explanatory element for the emergence of order and collectively accepted norms in system building (Krohn and Küppers 1992; Fagan 2009; Wagner and Leydesdorff 2005).

There is ample empirical evidence that social entrepreneurs and collective actors enact innovation models in different locations and situations in order to initiate collective action. ${ }^{4}$ This is essentially an export of beliefs in the cultural repertoire of transcultural entrepreneurs, a pattern newly acknowledged in the

4 For example, there are Triple Helix clusters in Lahore or Thessaloniki and many other places that apply the concept. More examples for Triple Helix settings are the Plasma Medicine 
innovation literature (Saxenian 2007). In this context, Patel and Conklin, and others, show how transnational entrepreneurs balance their network in scope and size in dual environments, with the help of models, to enhance their ability to operate in both environments (Basu and Pruthi, 2018; Drori et al. 2009; Elo and Freiling, 2015; Patel and Conklin 2017; Saxenian 1999, 2002, 2007; Saxenian and Hsu 2001). Evidently, established role models or blueprints in innovation play an important role for group coherence and for the integration of new group members as well as for strategic alignment. Along the same line of reasoning, Bercovitz and Feldmann reconcile individual behaviour and collective learning in the context of organizational and regional change (Bercovitz and Feldman 2008).

Interestingly, the concept of transcultural entrepreneurs extends beyond the role of a broker or "boundary spanner" in social networks (Burt 200o). It encompasses the capability to activate relationships in an entrepreneurial way and initiate collective action and enact identity of place in a primus interpares mode of leadership: "Social capital refers to actual and potential resources that exist within, and may be leveraged from, the network of relationships possessed by an individual or social unit" (Davidsson and Honig 2003; see also Brinkerhoff 2016; Chen and Tan 2009).

Therefore, we need to look deeper into the formation of social networks in order to shed light on the role of "small networks of dedicated actors" (Geels and Schot 2007) in the organization of urban transformation and path modernisation or path creation (Geels 2002; Massen 2012). To do so we employ Granovetter's concept of social networks, which refers to relationships or ties among individuals (Granovetter 1977, 1985). As a result, we reveal the institutional context for new forms of cultural and symbolic capital necessary in the development process (Presutti et al. 2007; Weick 1995; relational capital for a shared vision in innovation systems and groups: Scholz et al. 2009; Russel et al. 2015) and for technological change (De Liso and Metcalfe 1996). We also take into consideration that proximity and interaction facilitate the necessary interaction for trust-building, based on the findings of Schein and Senge, who studied feedback mechanisms from interpersonal relations on individual mindsets and behaviour and confirmed the impact of dialogue on cultural change and organizational learning (Schein 1968, 1993; Senge 1990). The studies give reason to believe that individuals are guided by role models and use these models as tokens to build organizational identity and new collectivism (Lewin 1947, Argyris 1990; Ross and Heap 1992).

cluster in northern Germany and the programmatic design for the federally funded solar cluster in eastern Germany (Gebhardt 2013). 


\section{Introduction of the case: smart, green and inclusive urbanism in Brainport smart district/metropolitan region Eindhoven}

City of Helmond is a Dutch municipality and a peripheral city in the metropolitan region of Eindhoven, in the province of Noord-Brabant in the Southern Netherlands. With a population of nearly 90,00o residents, Helmond is one of the five largest cities in Noord-Brabant province and lies within easy driving distance (about 17 minutes) of Eindhoven and therefore must be considered in the larger context of the development of "the top technology region" (Nauwelaers et al. 2013) Eindhoven.

In 2016, Helmond municipality had to meet a deadline for a development plan which included a large residential area with 1,500 housing facilities. ${ }^{5}$ The first attempt by Helmond municipality to start the urban development process of the smart district as a traditional housing construction project encountered difficulties and the beginning of the project was delayed. In September 2017, it was restarted with the name of slimme wijk brandevoort [smart district of Brandevoort]. Several departments of the University of Eindhoven prepared a so-called 'ambition paper' in a meeting with Fraunhofer Institute for Industrial Engineering IAO from Stuttgart in Germany, to set up Brainport smart district, as a "living lab" using sustainability criteria that had been identified in the Fraunhofer Morgenstadt city labs that are part of the international pool of benchmarking cities. ${ }^{6}$ In this way the Fraunhofer City of the Future/Morgenstadt initiative provided a strong role model addressing aspects such as the liveable, innovative, safe and healthy city (Bauer and von Radecki 2017). This smart sustainable city concept addressed topics such as energy grid solutions, mobility and resources efficiency, which all rely on data for operational connectivity and optimization of connected IT infrastructures. Eindhoven academics (some of them inhabitants of Helmond) adopted these characteristics for a sustainable urban development plan on the top of a long-standing tradition of science driven progress in the Eindhoven metropolitan region with a new

5 Brandevoort was built according to the principles of New Urbanism and New Classical Architecture. In 2014, the neighbourhood is home to approximately 9,000 people living in 3,000 houses and apartments. The plan is to have a population of approximately 18,000 and a total of 6,ooo houses and apartments. See: https://en.wikipedia.org/wiki/Brandevoort. Accessed 4 August 2018.

6 In the Morgenstadt initiative, the Fraunhofer institutes develop solutions for the so-called city of the future together with partners from industry and cities. Fraunhofer researchers identified nine sectors that are crucial for a sustainable urban development process: (1) Mobility; (2) Buildings; (3) Water supply; (4) Governance; (5) Energy; (6) Finance; (7) Information and Communication Technologies; (8) Logistics; and (9) Resilience. See: https://www .morgenstadt.de/en/about_us.html accessed o6 August 2019. 
smart sustainable approach to repurpose the building sector. The guiding spirit was social entrepreneur Elphi Nelissen, a Professor and Chair of Building Sustainability at Eindhoven University of Technology with an interdisciplinary professional background. ${ }^{7}$

Nelissen made a statement on her website: "I dream of a better world; of a society that is healthy, social, sustainable, and safe and in optimal balance with its environment; creating a smart city by making use of modern technology". Her ideas strongly influenced the objectives for the location: "My vision for Brainport smart district is that it must become an example for the rest of the world. To show what is possible, so that anyone can copy and upscale our findings" (interview with present author, 15 July 2018).

However, the data driven approach led to a growing resistance in the community. Residents feared the scenario of Brainport smart district becoming a sleeping town for academics commuting to Eindhoven (source: syntegration ${ }^{\circ}$ interviews).

Furthermore, there were concerns that academia would not be able to efficiently organize an integrated process for the "smart" residential area and there were fears in the local population that return on investment principles used by construction companies, and the "smartness", would lead to high house prices, high living costs and traffic problems because of commuters to Eindhoven. Equally, the Helmond inhabitants were suspicious of smart technology especially the data-driven control model to secure connectivity for technological self-adaptation of smart solutions in an autonomous way. Increasingly, inhabitants of the city opposed the idea of private data collection for smart services (energy, mobility, housing, etc.) and security (sensors, profiling and tracking) as it took place in Eindhoven and Utrecht. The governance model was driven by science and technology experts, and addressed in a project management style rather than to provide a concept for the social complexity that lay ahead (source: own interviews).

Nelissen responded retrospectively about the participative governance model she had in mind:

In my opinion the Brainport smart district is one of the many projects of Brainport. Of course, the Brainport region is much bigger than just the Brainport smart district. The Triple Helix plays an important part in

7 Her areas of expertise include renewable energy and the built environment, circular building economy, sustainable building, building services, building physics, building acoustics as well as girls and technology). https://research.tue.nl/en/persons/elphi-nelissen. Accessed $6 \mathrm{Au}$ gust 2019.

8 See: https://research.tue.nl/en/persons/elphi-nelissen. Accessed 6 August 2019. 
everything we do, although the Triple Helix was replaced by the quadruple helix, because the citizens are involved right from the start as the fourth member. (Interview with present author, 15 July 2018)

\section{Embedded in the metropolitan region of Eindhoven, Helmond inhabitants have seen frequent applications of the Triple Helix model in the regional de- velopment path by the corporate player Philips. ${ }^{9}$ Turning points like the}

9 The regional context: Business driven innovation in Eindhoven and the role of Philips:

The consolidation of six villages to a new town, Eindhoven, in 1920.

The organization of social infrastructure by Gerard Philips, a corporate entrepreneur who became a commercial entrepreneur because the liberal-Protestant Philips family was excluded from the networks of the Roman Catholic region. Thereafter the Philips Company built dwellings, schools, shops, sports and recreational amenities (with a theatre and a cinema) and laid out green spaces. In addition, Philips provided medical services and organized several sport clubs (Havermans et al. 2008).

When Philips started manufacturing incandescent lamps in 1891, there was already a separate industrial research laboratory outside the factory; this was an innovative concept that was virtually unknown elsewhere. In 1914 another major step was taken, with the opening of a physics laboratory (the "Nat. Lab.").

In the 1970s, Eindhoven experienced a major crisis when Philips moved its headquarters to Amsterdam, concentrated on its core business and moved manufacturing activities to other locations, leaving only R\&D facilities in Eindhoven.

In the 199os Philips built on the work of the government-driven development funded by National and European programs, expanded research activities in Eindhoven and became an active player in its (Eindhoven's) renewal.

In 1999, Philips Research Eindhoven initiated the High-Tech Campus (HTC) Eindhoven, which became the center for technology-enabled innovation in The Netherlands. Later, Philips turned the HTC into an open campus, targeted at fostering open innovation and cooperation between different companies and institutes. In this way Philips has built an innovation district, an environment that fosters interaction, networking and knowledge sharing, and ultimately encourages the participation of research organizations, manufacturers and startups to jointly develop ground-breaking technologies (Blau, 2007). The company introduced the Triple Helix innovation model as a design principle for the science park. Today, the HighTech Campus houses more than 140 companies and institutions with over 10,000 researchers, innovators and entrepreneurs representing 85 nationalities (Blau, 2007).

Eindhoven used the Triple Helix Cluster approach as a blueprint for cluster development: Brainport Development, a regional economic agency, is addressing the NUTS region of Zuidoost-Noord-Brabant in The Netherlands. Brainport Development works with representatives from industry, knowledge institutions and public authorities, in Triple Helix fashion, to strengthen the Brainport Eindhoven high technology region. The high technology and materials sector employ more than 6o,ooo people and includes nearly 7,00o companies in what is a relatively small geographical area (750,00o inhabitants).

In the Brainport Eindhoven Region, Brainport Development emphasizes the potential of regional assets, using a bottom-up approach for clusters in the business sector, and consults firms, which seek solutions for long-term issues such as technological transformation and innovation. The agency uses a project-based approach for innovation cluster development. 
research and science driven development after a period of decline, the relocation of Philip's manufacturing facilities and the influential role Philips played for social innovation in the region are occurrences that highlight the innovation model repertoire of the Eindhoven metropolitan region and provide strong narratives for the creation of regional pathways (Paasi 2003). The value of science is deeply imprinted in the quasi-genetic code of the area and allowed for new routines born in these transformation periods, such as corporatist networking and open innovation that both generated many innovation clusters in the form of interconnected Triple Helix science, industry and government relationships. In addition, The Netherlands has an experimental approach in policy innovation and regional transition (for instance DRIFT, a research institute of Erasmus University in the field of sustainability transitions with a focus on the urban context and participatory sciences. The Academy connects education, practice and research to create innovative learning tracks). ${ }^{10}$

Because of her professional affiliation and areas of research (sustainable building and energy), Nelissen and other Eindhoven academics would have been exposed to these ideas of networking clusters and Triple Helix innovation, participatory models and smart cities as models for the region (Deakin and Leydesdorff 2014). It was the social entrepreneur's idea to apply these concepts to a residential area in order to provide an anchor point for other actors to buy into the process. ${ }^{11}$

The consulting repertoire addresses sharing knowledge, exchanging networks and creating added economic value, entrepreneurship and new businesses.

These clusters are extended to cross-border collaboration between Aachen, Leuven and Eindhoven as part of the OECD regions and innovation program. Further, Eindhoven City is a "lighthouse smart city" and, with Manchester (England) and Stavanger (Norway), part of the Triangulum project funded in the European Union Horizon 2020 Research and Innovation program, with a five-year duration (from 2015-2020) and a €29.5 million budget, of which $€ 25.4$ million is direct EU funding. The project is managed by the German Fraunhofer Institute of Industrial Engineering, IAO, which, with the Steinbeis European Centre, is also the co-lead body for the project. Triangulum aims to become a blueprint for smart cities with a focus on data, building and mobility.

10 See: https://drift.eur.nl/. Accessed 6 August 2019.

11 EN: [...] "Of course we will see if this is true. We want to set up a living lab there, in which we will apply all available knowledge from Eindhoven University of Technology and other parties to learn from it. In that Brainport smart district, autonomous vehicles will drive. There is room for local energy generation and for new types of buildings, which meet the need for communal areas. But we also try to create a healthy environment: by encouraging people to exercise and to monitor that. That will reduce loneliness, improve health, make life easier and perhaps even lead to a more inclusive society in which people 


\section{Research design of the case study: the syntegration method applied in a real-world laboratory learning approach}

The research was carried out in a semi-controlled living lab in 2016 and 2017. Action research, workshops as well as about 50 interviews took place alongside a theme-centered interactionism process and in a large-scale workshop called syntegration ${ }^{\circ}$. Interviews were carried out randomly to validate the findings. The case was selected because the municipality tested a participatory governance approach. Running a RWL with syntegration ${ }^{\circ}$ offered the opportunity to rely on a proven setting for stakeholder integration, to speed up the proceedings, to gain higher process transparency and to achieve higher planning security for Helmond administration. Other consultation and brainstorming processes based on world café methods with a large number of people were rejected because of their limits when it comes to binding implementation of action points.

The operationalization of the research shows the usual deficiencies of RWL: (1) In our case it relies on a selection process for participation in the RWL made by a core team from science and administration in Eindhoven and Helmond. To mitigate the bias the process was managed by Helmond city administration as an open call and with predefined selection criteria (Triple Helix representatives and members of social interest groups of Helmond city and the metropolitan region and smart city experts). (2) The RWL allowed only for a small group of participants ( 42 and guests). That was mitigated by the open invitation of Helmond, which addressed a larger sample with the following criteria: (i) multi-level: local, regional, national government, multi-scalar; (ii) Eindhoven and Helmond, one smaller reference city; (iii) interdisciplinary: smart technology experts, STEM fields (science, technology, engineering mathematics), industry and social sciences from Tilburg University, multiplying actors: SPARK, Fraunhofer; (iv) laymen and non-governmental organizations such as labour offices, schools, and local and national media to build a robust critical mass and acceptance. (3) The case lacks a control group and (4) captures only the early stage in the citizen-driven development path, which might be a tem-

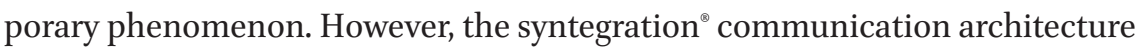
employed for the RWL, and tested in that setting provides a controlled process design that facilitates future comparative analysis.

develop less distance from the labor market." See: http://hybridspacelab.net/project/ technology-and-the-city. Accessed 6 August 2019. 
The syntegration ${ }^{\circ}$ process foresees a pre-phase ( 2 workshops prior to the closed 3.5-day workshop lab involving 42 participants). The closed syntegration ${ }^{\circ}$ workshop lab is based on a theme-centered interactionism process established on cybernetic communication rules and on closed feedback loops (Beer 1994). ${ }^{12}$ The method provides a robust working plan for the pre-phase and a networking communication structure for 42 syntegration $^{\circ}$ participants in the lab. The main event - or closed workshop - is optimized, by an algorithm, for maximal direct contacts/interaction points between participants in a given time. The structure is non-hierarchical - there is no top or bottom in the icosahedron. ${ }^{13}$ Due to the syntegration ${ }^{\circ}$ principles and the modus operandi "each participant has the same opportunities to influence the result" (Pfiffner 2004). The method is rigidly structured (tight schedule, role definition and facilitation as well as documentation) in order to suppress overactive individuals.

The process starts with two brief workshops prior to the large-scale workshop. In our case the municipality of Helmond invited the social entrepreneur and other scientist and political stakeholders to discuss the status of the project, the objectives of the regional innovation project and the living lab conditions. The workshops resulted in an opening question for the syntegration ${ }^{\circ}$.

That step was followed by the closed-workshop (3.5 days), in which the same group of participants from different backgrounds developed 12 themes from a regional innovation problem in relation to the opening question, in grassroots fashion in a marketplace situation.

In the following, participants were (self-)assigned ${ }^{14}$ to the 12 themes the entire group of 42 participants had created in the marketplace. "Gentle" facilitation was used in every theme and for the lead process. The participants acted in different roles; that is, they were participants in two themes and critics in two different themes. During the 3.5 days of the syntegration ${ }^{\circ}$ the roles of every individual were participant, critic and observer, other than in plenary discussions. The themes were discussed in three iterations by seven participants (and critics) using short, parallel workshops. Every theme was explored in three iterations of the same theme with different objects (current situation, future and action plan) respectively.

12 See: http://www.syntegration.com/_file/o9_From+workshop+to+syntegration.pdf. Accessed 6 August 2019 .

13 In this context the icosahedron is the visualized communication structure, based on cybernetic principles.

14 Participants give an input before algorithmic modelling such that they estimate their contribution to the themes. 
The emergence of the 12 themes, the facilitated discourse and the development of solutions were documented in real time and distributed to all groups during the process. A total immersion exploration research team observed the process and the discussions while the syntegration took place. Interviews of participants preceded and sat alongside the syntegration ${ }^{\circ}$. They were used to validate some of the results, but there was no systematic exploration of the interviews. The results were presented to the whole group every day.

\section{$7 \quad$ Research results: three stages}

\subsection{System formation and pre-workshops}

In the autumn of 2016, the municipality - as a response to resistance - adopted a new approach in order to get the project started. This involved the proposed living lab design but with a different method. Instead of many small, sequential workshops held by science and technology experts and the municipality, they opted for the syntegration ${ }^{\circ}$ process to test a participatory model of regional innovation that involved all stakeholders simultaneously. This new course was financed by matching funding from the municipality and the province. ${ }^{15}$

Further to this decision, the municipality set up two strategy meetings to clarify and address the following points and objections:

1 How do we create a district in which all the different aspects of a "smart city" come together; a district that allows us to do research on the needs and deeds of its inhabitants, and a district that at the same time offers a safe, social and pleasant environment for its inhabitants?

2 How do we work together in this project in a way that does justice to everyone's objectives and expertise, ensures an efficient and effective process and at the same time clears the way for creativity and innovation? ${ }^{16}$

15 "We discussed your offer with our Alderman []. Like us, he is enthusiastic about the syntegration method. Today he spoke to a representative of the Province Noord-Brabant to effectuate a co-financing $(50 \%)$ of the process. [...] Brainport smart district has been designated by the Province as 'Proeftuin [living lab] van Brabant'. [...] We expect that the process of decision-making by the Board of the Municipality of Helmond will come to a conclusion on November 15th or at the latest at November 22th". Email from the program manager, Brainport smart district. Strategie en Programma's Gemeente Helmond on 10 October 2016.

16 Participants: Program officer smart city center, TU/e (Eindhoven University of Technology), researcher Department of the Built Environment, TU/e, trainee Brainport smart district, municipality of Helmond, strategic advisor Brainport smart district, municipality of 
In the first strategy meeting the initial (small) group defined the boundary conditions of Brainport smart district ${ }^{17}$ and clarified the objectives for the opening question of the large-scale workshop that was part of the living lab process. This provided orientation with regard to possible participants and expected results. The small group acknowledged that a participatory approach would help citizens to understand and accept the project and that they, the group, would take the risk of alteration of the original concept which was sufficiently vague to permit changes. The group confirmed the method for the process and they also discussed the expectations with regard to outcomes.

(a) Ideally a new collective interpretation framing would develop and the groups would turn from a brainstorming into an implementation team with a new reference frame.

(b) A further desired organizational outcome was the assignment of participants of the syntegration to a consortium or decision-making board, and to interconnected key projects to be developed in the syntegration.

In the workshops the small group outlined the opening question of the workshop to invite citizens to a constructive collaboration and to become actively involved in designing the appropriate governance ("What" and "How"): "What do we need to start today to make Brainport smart district by 2022 a lighthouse as the most liveable adaptive residential area using cutting-edge research and technology enhancing socio-economic development?"

Accordingly, they defined a long list of participants who were selected with the help of a matrix, which matched quadruple helix selection criteria (academia and smart city science experts, government representatives from different political levels, inhabitants of both cities, companies which produce smart city solutions, representatives from social interest groups): there were 116 possible names invited in an open call. Potential participants were approached by members of the small group and by an open invitation letter for taking part in the large-scale workshop from the municipality, which resulted in a short list and to the final setting (see Appendix 1).

Helmond and the program manager Housing and Brainport smart district, municipality of Helmond (the meeting took place on 21 October 2017).

17 The group consisted of: TU/e Smart Cities Program Coordinator; Tilburg University; Spark-Campus; Provincie Noord-Brabant; Gemeente Helmond: Program Manager and Project Manager Area Development Brainport Slimme Wijk), and Project Managers. The second meeting included also members from German Fraunhofer institute IAO and a local Media expert. 


\subsection{Lab/closed large-scale workshop (3.5 days)}

In the closed syntegration workshop the open agenda was filled with themes that could provide answers to the opening question ${ }^{18}$ in a marketplace design on the first day and by the participants themselves. The participants agreed on 12 interconnected themes and developed an idea of the first actions.

The themes were: (1) Resilient city (i.e. adaptable city); (2) Open infrastructure (adaptive and supporting change); (3) An area with an energy (community owned, autonomy, environmentally sound; dimension of the grid, off grid solutions); (4) Data (data is an enabler of smart environment, rules for sharing and privacy of data); (5) Health and wellbeing in a participating society (healthcare, hospitals and decentralized services); (6) Attractive built environment (the way we build houses, including safety aspects and social inclusion which relate to bricks, bytes and behaviour); (7) Diverse participation (diversity in regard to population); (8) E(uro)cosystems (business models and organization of the ecosystem and taking decisions on social and economic services); (9) Implementation (process design, assignments, design principles and governance); (10) Mobility in Helmond, and to and from Helmond - Eindhoven (public transportation, car sharing, e-mobility, autonomous driving); (11) Green selfsustainable city (green environment and self-sustainable city, regenerative eco village 2.0 standard); and (12) Everything as a service (from ownership to a sharing economy).

Contrary to earlier expectations, the group failed to produce either an integrative science concept for the building site, or a scheme capable of being used to start the project. However, they did agree on design principles or a constitution for the adaptive governance of the innovation path, on a permanent social society committee and a trial and error design for a scheme. Some of the 12 themes above were changed into an integrated approach to bridge institutional silos for integrated socio-technical solutions. Pilots and concrete actions were selected, for instance:

- "An area with energy" (grid integration for efficient use of energy and use of renewable energy);

- Integration of "health and wellbeing" into construction and planning (new materials but also connecting hospital(s) and other health providers in the new community);

18 "What do we need to start today to make Brainport smart district by $2022 \mathrm{a}$ lighthouse as the most liveable adaptive residential area using cutting edge research and technology enhancing socio-economic development?" 
- Adding the new perspective of resilience and adaptable solutions (in terms of 'social knitwear' of the community and climate resilience);

- Topics such as affordable housing, the recycling of water and plastics and a sharing community that has a focus on local value creation and circular economy models;

- An academy (educational establishment) to train city administrators; and, last but not least,

- Mobility within, to and from Helmond, taking into consideration the commuter situation of Eindhoven and planning the traffic routes with public transport and the Automotive Campus Helmond.

The theme group offered this statement of desired features:

The "attractive build environment" would include ideas like landscape architecture, regaining urban space, urban farming initiatives and the efficient and flexible planning of housing so that "construction became more than a brick and mortar business", but also data.

The key outcome was a collectively acknowledged code of conduct, exploring in full the knowledge inventory and the establishment of jointly agreed normative rules and critical elements for the subsequent process of the organization of urban and regional innovation. Individual attitudes were mitigated to a constitution and the tacit knowledge was converted to explicit design principles for the transformational governance.

- A scalable and adaptive concept;

- Variety/complexity as a resource and not a threat;

- A holistic concept in the way that smartness is more than technology and includes social innovation (a sharing and circular economy); and

- A flexible integration process to allow entrance and exits of members and stakeholders without losing critical mass and momentum.

Known smart city best practices were to be applied, when accepted, for example, cycling paths, garbage collection and disposal systems, regaining public space, greenness and saving energy. Financial schemes that contradicted the values would not be accepted. The group set up an implementation team that was then given the assignment to organize and formalize participatory governance and citizen participation in Helmond and to become a standing committee. 
In summary, the lab design and the methodology had provided the means for discussing and interpreting the assumptions and pre-conditions, the interfaces and interconnections, as well as the organization of urban/regional innovation, rather than to talk about the science and technology topics alone. The staffing was important because it changed an isolated residential construction district into a social innovation program for and with the local community and stakeholders, as part of a regional development of the Eindhoven metropolitan region and within the national innovation system of The Netherlands.

Because of the need to explain science and technology solutions to laypeople and big data adversaries in the workshop, the special interests of individuals and the high-level concept were leveraged. For example, in the marketplace of the large scale workshop the majority of participants wanted to vote the DATA theme out; but then decided to keep it as an essential point that needed to be discussed in every theme for the connectivity of mobility, energy, housing, grid, dealing with participation and data privacy concerns. All of the theme groups acknowledged that the new neighbourhoods needed to integrate ICT into the governance model: that is, rules were therefore needed for data sharing, privacy of data, ownership of data, trusted zones, decisionmaking, decentralized and central data storages, off-the-grid solutions, fallbacks for resilience, and so on.

\subsection{Post-lab phase}

The phenomena of strong team-building effects, and strong commitment by peers and increasing levels of interest shown by citizens, were evident. In the lab, participants in the accelerated interaction process created new joint narratives, symbols and stories that built up trust and facilitated further interaction and cooperation, which might help to overcome institutional barriers and time constraints permanently. The participants stated that with this new frame of reference they would continue the process. They created a steering committee to maintain the element of collectivism in the process. The social entrepreneur who had started the process became a member of the steering committee; but, notably, had not dominated the agenda and themes - although building and planning became one of the strategic projects.

The social entrepreneur adopted an organizational role after the large-scale workshop, becoming a member of the board of Brainport smart district committee with other participants from different spheres (academia, banks, government and science) and professional backgrounds. She is still very closely 
involved in the proceedings. ${ }^{19}$ Although the network is widespread, it remains interconnected and there are many simultaneous and integrated activities in the region. It appears that the case provides a citizen-driven transformative governance model for other municipalities both in the region and adjacent to metropolitan centers and is disseminated by media and marketing agencies.

Importantly, the decision to form a formal steering committee with representatives from the syntegration ${ }^{\circ}$ - who were nominated during the process has reduced the risk of (a) lock-in, (b) regression into old technological trajectories, and (c) the dependence on the vision of a single individual or actor that would affect the sustainability of the development path in a negative way. This can be regarded as a step towards the institutionalization of a new path and towards sustainability. In this visible and institutionalized form, the consortium has decision-making authority in the municipality. The workshop themes are set up by project managers who also become part of the steering committee and meet each other to monitor progress and lessons learned, and to check the coherence with design principles. Institutionalized as a legal entity the project is now eligible for funding in programs such as eHealth, the Smart City, the European Regional Innovation Strategy (RIS), interregional and technology-specific programs, and as a lighthouse for other cities abroad (e.g. in Vietnam). There is an active recruitment of new local NGO players such as the DATAstudio at the Het Nieuwe Instituut, ${ }^{20}$ which organizes cultural events in order to engage in dialogue with citizens via the arts. Currently, many other projects accompany the smart district and residential development in Brainport: the idea has gathered momentum.

A year after the workshop, the Project Secretary of the Brainport Smart District stated:

'The syntegration ${ }^{\circledR}$ process was a start for the organization of further developing Brainport smart district, with interconnectivity as a central focus in the way we organize ourselves. Several participants still participate in the different projects we are running now. Some participants are also members of the project team (soon to be a foundation) and institutions and companies are still highly involved. The syntegration ${ }^{\circ}$ [the structured syntegration $^{\circ}$ process of the living lab and the large-scale workshop] including the reports, also provided us with a language to stay sharp in this project. I mean sharpness when it comes to the right ideas and the right people to involve.' (Interview with present author, 3 May 2018)

19 The BSD board selected an urban designer (Nelissen interview 15 July 2018).

20 See: https://destaatvaneindhoven.hetnieuweinstituut.nl/en. Accessed 6 August 2019. 


\section{Discussion}

In the case study presented here the involvement of social entrepreneurs and local citizens under the umbrella of the local administration, led to an evolutionary transformation and path modernisation in urban and regional development in a high technology region. A participatory governance and civil society driven concept resulted in new design principles for the organization of regional innovation and the alteration of a concept of the technocratic smart city to provide for social innovations and inclusive growth. Citizens changed the governance of science in the process and adopted a new role for citizen engagement in science-driven urban development.

The results of the research illustrate the role of the social entrepreneur, in our case an academic social entrepreneur with a scientific background. In the process of bonding and system building, Nelissen's status became that of a member, with an equal role in the process. She reflected and adopted inputs from new sources, such as the resilience program of the Rockefeller Foundation. ${ }^{21}$ She attracted followers in her theme 'open infrastructure', but her construction and planning ideas became integrated in all themes, as did the data and energy issues. We conclude that in transformation the initial focal point seems to be a social entrepreneur who acts as an anchor - a person who starts the process of system building. In the learning approach of RWL, actors from different institutions and backgrounds developed a shared understanding of social entrepreneurship as a responsibility for the transformation of urban and regional space and stabilized this new mission with an interconnected action plan. It turns out that methods and concepts - narratives of symbolic nature rather than normative blueprints - help to attract and retain other individuals and organize regional innovation prior to formal institutionalization. The cooperative style of the Triple Helix, or the smart city approach, and the history of the location can work as - to put it simply - the glue that helps to form a social network and attract others.

The personal characteristics of our social entrepreneur match those that are repeatedly found in social entrepreneurs and in literature: charisma, boundaryspanning activities, a track record of social innovation, acknowledged expertise in one field and interdisciplinary interest in others and, above all, a self-reflexive capacity. The social entrepreneur in our case was, for professional reasons (sustainable building and planning), also a social and regional entrepreneur.

21 See: http://www.10oresilientcities.org/. Accessed 6 August 2019. 
There appears to be a first tipping point where the self-esteem of an individual is replaced by another mode of organization and self-reflexivity that is applied at group level in the syntegration process. At that point, new characteristics become more relevant - for instance, bonding with peers, mutual learning, acceptance of compromises, use of innovation role models as a bondage, use of relational capital such as cultural patterns, routines and local heritage - as well as managerial knowledge on governance of complexity and organizational readiness for change. These features become important for retention of old and recruitment of new actors, which is itself an important step on the road to realization of concepts because such actor constellations provide the critical mass necessary for further action.

New methods such as the syntegration process and real-world laboratories and living labs offering proximity and frequent interaction, and accelerated social networking, might not only provide an observation space for research on organizational change and social network formation in a critical stage from individualism to collectivism; the semi-controlled lab also works as an incubator, in that it facilitates the liberation and change of mindsets. The working and communication structure facilitated the transformation of a heterogeneous actor constellation into a problem-solving collectivism for the complexity inherent in the challenge. At the same time, it may have prevented co-optation and an early closing of the new system.

It is reasonable to expect that the emerging repertoire of co-creation methods in social innovation might become more widespread as a method for efficient participatory governance in complex urban transformation processes, and a legitimate way to initiate organized collectivism (faster) as well as to maintain it (via framing, shared beliefs and organizational design and formal institutionalization and new routines for new pathways).

At the moment, the signs for a sustainable Brainport path modernisation case are favourable, because the group adopted responsibility as a collective social entrepreneur, defined an implementation team, and the transition process, and a sounding board to sit alongside the process of implementation under a new set of design principles. However, if path development is not governed in terms of interconnectedness, social and regional entrepreneurs are in danger of becoming co-opted, and of falling prey to institutional rationalities of their home organization and strong expert groups could regress into traditional, exclusive innovation models and routines if the new collective has no institutional framing and funding. Following our research, we conclude that the participatory governance model is a condition sine qua non for sustainable transformation. It is a social innovation per se. Also, the case shows that 
transformative governance must remain adaptive and interconnected in the implementation process to face wicked problems that may un-intently occur in future. Conflicts inherent in smart sustainable urban development cannot be solved ex ante but need monitoring and value-based decision-making alongside the process of realization.

Last but not least, the degree of variety (knowledge, rationalities, and backgrounds) and the number of people involved in the process seem to be success factors in that way that a critical mass with a shared belief system can become a group that stays interconnected and can follow through to build a new regime (Geels 2002).

The findings clarify the concepts used in the frame of reference:

1. Social movements are an incubator room for solutions that address wicked problems which arise when climate policies, sustainable and inclusive development and smart, data-driven technology meet in cities and regions.

2. Participation: The open and transparent invitation process of the syntegration turned out to be a crucial step for the acceptance and sustainability of the results. The size and variety of the participant sample is another important element in the process - as only variety can cope with the variety inherent in wicked or complex problems. Following this, there are three crucial elements for sustainability of participative and adaptive governance: critical mass (sufficient number of involved actors), variety and self-reflective capacity to ensure on-going and open innovation.

3. Sustainability: Intangible factors such as urban space, clean air and social interaction have a societal value; the value can be assessed by the community and can be considered in circular economy models. The profit is a social and local profit and the "business" model a sustainable model that has a long-term value.

4. Real-world laboratories: Isolated urban brainstorming events and temporary citizen engagement are not adequate for system building and sustainable transformation. Long-time process designs that facilitate social coherence, assign new responsibility to citizens and public administration.

5. Transformative and adaptive governance speeds up solution building and implementation. The design principles developed in Brainport Smart District must be further tested and employed in city management.

6. Participatory governance in its multi-level, multi-scalar dimension is a social innovation in itself and a process innovation. The actor-centered 
approach shows that members of the newly formed collective change the future governance of science, the regional development path and define the societal use of knowledge in a specific urban space.

7. The Triple Helix model and the smart city concept provide strong narratives for action (for instance: criteria for selection of participants) and formed a joint belief system in Brainport smart district for collective action. Both high-level concepts cannot provide precise action plans for operationalization as the syntegration ${ }^{\circ}$ would do. However, they were used as tokens to build collective action.

8. Social entrepreneurs rely on framings such as innovation models, symbolic capital and routines for system building and bonding. Their professional background (science, industry, engaged government administration and non-profit) plays a role but the dominance of the feature is surpassed by capability and motivation to take on a social and territorial responsibility. Social system building is a critical point in the process where the economic evolutionary developmental path of the location is enacted, redefined or renounced with the help of belief systems.

9. The implementation of policies and high-level concepts in the urban and regional context relies on methods and tools that capture the systemic and dynamic nature of the transition process.

10. There must be further research to test transferability, validity and reliability of governance models for regional path development. The research can employ the structured syntegration process and the RWL method as they proved to be reliable research designs. Further comparative research on transformative governance can be based on a preliminary categorization that follows our research (Table 1).

The case of Helmond smart district in the high-tech metropolitan region of Eindhoven is an example of an urban transformation process embedded in a regional context, which was started by a social entrepreneur and as a citizendriven innovation with a strong role for local government and administration. An urban perspective was adopted to understand how mitigation and adaptation practices take root, develop over time and reinforce or modify the regional development path (Anguelsvoski and Carmin 2011; Martin and Sunley 2006; Martin 2014).

The findings of the research help to better define two contrasting ideal types of developmental pathways characterized by the key concepts applied for the research. Different expression can be evoked for a tentative categorization of evolutionary and disruptive/revolutionary development paths. 
TABLE 1 Tentative categorisation of urban and regional development pathways

$\begin{array}{lll}\text { Urban/regional } & \text { Evolutionary } & \text { Disruptive/revolutionary } \\ \text { development pathways } & \text { (expressions) } & \text { (expressions) }\end{array}$

\begin{tabular}{|c|c|c|}
\hline \multirow[t]{7}{*}{ Governance } & $\begin{array}{l}\text { Bottom-up/, citizen driven, social } \\
\text { entrepreneurs, networks }\end{array}$ & $\begin{array}{l}\text { Top down, bottom up, science, policy or } \\
\text { business entrepreneur driven }\end{array}$ \\
\hline & Participatory (stakeholder) & Indirect governance (rules and legal \\
\hline & Transformative (alongside the & framework for entrepreneurial business \\
\hline & realization process) & activity) \\
\hline & Adaptive (experimental) & Industry values, or consensus space of \\
\hline & Civil society and public & institutionalised Triple helix relationships \\
\hline & administration values & (Industry, University and Government) \\
\hline \multirow[t]{4}{*}{ Social entrepreneurs } & From individualism to collectivism & Individual entrepreneurs \\
\hline & Urban and regional perspective & Profit/growth driven perspective \\
\hline & Self-reflexive capacity & Collaterals accepted (decline, exclusion, \\
\hline & Use of social and relational capital & social or spatial disparity, etc.) \\
\hline \multirow{5}{*}{$\begin{array}{l}\text { Social innovation/ } \\
\text { innovation }\end{array}$} & Integration of social sciences & STEM and business innovation \\
\hline & solutions and societal values & Economic failure/success \\
\hline & Halting or repurposing of science & Emergence of industries \\
\hline & and business driven development & Integration into global value chains, \\
\hline & & Relocation of industries possible \\
\hline \multirow[t]{6}{*}{ Principles } & Sustainability & Innovation (success in markets) \\
\hline & Innovation (overcoming the tragedy & Complexity as an (investment) problem \\
\hline & of commons) & Exclusive \\
\hline & Complexity as a resource & Windows of opportunity as a gate for a new \\
\hline & Holistic, transparent, inclusive, & path or failure \\
\hline & ongoing & Financial return on investment \\
\hline \multirow[t]{5}{*}{ Models employed } & Triple Helix & Same models \\
\hline & Smart cities & Economies of scope and scale \\
\hline & Narratives (history of place) & Supply chain/business ecosystem, etc. \\
\hline & Global values/Sustainable & \\
\hline & development goals (SDG) & \\
\hline \multirow[t]{5}{*}{ Methods } & RWL & Same Methods \\
\hline & Syntegration ${ }^{\circ}$ & Strategic planning \\
\hline & World café & \\
\hline & Design thinking, etc. (experimental & \\
\hline & and participatory) & \\
\hline Outcomes & Resilient & Competitive \\
\hline
\end{tabular}




\section{Conclusions and outlook}

The small satellite town of Helmond in the metropolitan region and global research hub Eindhoven have actively confronted the wicked problem of providing smart, green and inclusive urbanism and sought legitimacy by employing a co-creation process in a living laboratory that integrated civil society. Brainport smart district reminds us that a vibrant civil society transects conventional institutional spheres and provides a platform for path emergence and path modernisation or diversification. Furthermore, new systemic and dynamic approaches allow for experimental designs that address the complexity inherent in the process. The study confirms that a metropolitan region requires a series of interrelated self-renewing events, shared narratives and an open discourse in a democratic society to become viable through generations.

Furthermore, it invites us to rethink governance of sciences and the polity that enables and safeguards participatory governance models that give civil society a voice. Who shall assume a legitimate leadership role in orchestrating policy implementation and social innovation at the urban and regional levels and to develop a sustainable development path? Helmond municipality demonstrates that the role of the state in the form of public administration needs renewed research interest. Public administration however very often lacks the organizational readiness, the skills and the absorptive capacity for innovation, as well as the capacity to try out new participation processes that are both innovative and transformative in character (Termeer et al. 2015).

This is the case even though administration represents the unbiased player, with the most stable situation and a long-term interest for the wellbeing of citizens. The Dutch case shows that Helmond municipality picked up the thoughts of the social entrepreneur and then assumed a leadership role in orchestrating innovation at the local level and in the multi-level political arena. As a result, administration provided an adequate setting in which to intervene for a more inclusive and sustainable urban development - and enabled the definition of adequate rules in a political framework. The municipality actively bridged organizational silos and engaged in social innovation, even in multi-level governance, and in enabling sustainable regional innovation organization. They ensured that the roles of citizens and their interests, and those of social entrepreneurs, were reintroduced in innovation. The role of the state must therefore be reconsidered as an important player that defines the legal and cultural frameworks that mitigate the dilemma of exclusion in the capitalization of knowledge and provides new rules and routines for integration (Fukuyama 2011). This can be a solution for the problem 
of dissipation of citizen interest and for the tragedy of the commons in general.

The chosen approach introduced an interdisciplinary actor-centered approach to the paradigm of evolutionary economic geography to explain the social dynamic inherent in urban transformation. It allows for a fresh perspective to analyse how and why fuzzy and vague ecosystems that are offered many path options move towards a distinct institutionalization. Further, it provides insights into the tipping points, and emerging interdependencies of social and technical worlds, which are relevant for urban and regional systems in transition and must be considered in the governance models and political intervention schemes in complex conditions.

\section{References}

Anguelovski, I., and Carmin, J. (2011). Something Borrowed, Everything New: Innovation and Institutionalization in Urban Climate Governance. Current Opinion in Environmental Sustainability 3 (3), pp. 169-175.

Argyris, C. (1990) Overcoming Organizational Defenses. Boston, MA: Allyn \& Bacon.

Baasch, S., and Blöbaum, A. (2017). Umweltbezogene Partizipation als gesellschaftliche und methodische Herausforderung. Umweltpsychologie 21 (2), pp. 11-33.

Barendsen, L., and Gardner, H. (2004). Is the Social Entrepreneur a New Type of Leader? Leader to Leader 34, pp. 43-50.

Basu, A., and Pruthi, S. (2018). The Relationship between Prior Start-up Experience and Social Ties in Transnational Entrepreneurship. Paper presented at the RSA Conference, Lugano, Switzerland, June 2018.

Bauer, W., and von Radecki, A. (2017). Innovationsnetzwerk Morgenstadt: City Insights. In: Ressourceneffizienz. Berlin: Springer.

Baecker, D. (1999). Organisation als System. Frankfurt am Main: Suhrkamp.

Beer, S. (1994). Beyond Dispute: The Invention of Team Syntegrity. Chichester:John Wiley \& Sons.

Bercovitz, J., and Feldman, M.P. (2008). Academic Entrepreneurs: Organizational Change at the Individual Level. Organization Science 19 (1), pp. 69-89.

Blau, J. (2007). Philips Tears Down Eindhoven R\&D Fence. Available at: https://www. questia.com/library/journal/1G1-171139458/philips-tears-down-eindhoven-r-dfence. Accessed 1 April 2016.

Boschma, R. (2017). Relatedness as Driver of Regional Diversification: A Research Agenda. Regional Studies 51, pp. 351-364.

Boschma, R., Coenen, L., Frenken, K., and Truffer, B. (2017). Towards a Theory of Regional Diversification: Combining Insights from Evolutionary Economic Geography and Transition Studies. Regional Studies 51, pp. 31-45. 
Boschma, R., and Frenken, K. (2018). Evolutionary Economic Geography. In: Clark, G., Gertler, M., Feldman, M.P., and Wójcik, D., eds. The New Oxford Handbook of Economic Geography. Oxford: Oxford University Press, pp. 213-229.

Brandsen, T., Cattacin, S., Evers, A., and Zimmer, A., eds. (2016). Social Innovations in the Urban Context. Heidelberg: Springer International Publishers.

Braun, T, Ferreira, A.I., and Sydow, J. (2013). Citizenship Behavior and Effectiveness in Temporary Organizations. International Journal of Project Management $3^{1}$ (6), pp. $862-876$.

Brinkerhoff, J.M. (2016). Institutional Reform and Diaspora Entrepreneurs: The In-between Advantage. Oxford: Oxford University Press.

Bueren, E.M., Klijn, E.H., and Koppenjan, J.F.M. (2003). Dealing with Wicked Problems in Networks: Analyzing an Environmental Debate from a Network Perspective. Journal of Public Administration Research and Theory 13 (2), pp. 193-212.

Burt, R.S. (2000). The Network Structure of Social Capital. Research in Organizational Behavior 22, pp. 345-423.

Carayannis, E.G., and Campbell, D.F.J. (2010). "Mode 3" and "Quadruple Helix": Toward a 21st Century Fractal Innovation Ecosystem. International Journal of Technology Management 46 (3-4), pp. 201-234.

Chell, E. (2007). Social Enterprise and Entrepreneurship: Towards a Convergent Theory of the Entrepreneurial Process. International Small Business Journal 25, pp. 5-26.

Chell, E., Nicolopoulou, K., and Karatas-Özkan, M. (2010). Social Entrepreneurship and Enterprise: International and Innovation Perspectives. Entrepreneurship \& Regional Development 22 (6), pp. 485-493.

Chen, W. and Tan, J. (2009). Understanding Transnational Entrepreneurship through a Network Lens: Theoretical and Methodological Considerations. Entrepreneurship Theory and Practice 33 (5), pp. 1079-1091.

Certo, S.T., and Miller, T. (2008). Social Entrepreneurship: Key Issues and Concepts. Business Horizons $5^{1}$ (4), pp. 267-271.

Chomsky, N. (2012) Occupy. New York: Zuccotti Park Press.

Cohen, W.M., and Levinthal, D.A. (1990). Absorptive Capacity: A New Perspective on Learning and Innovation. Administrative Science Quarterly 35 (1), pp. 128-152.

Conklin, J. (2005). Wicked Problems and Social Complexity. In: Conklin, J.Dialogue Mapping: Building Shared Understanding of Wicked Problems. New Jersey: Wiley. Cooke, P., and Leydesdorff, L. (2006). Regional Development in the Knowledge-Based Economy: The Construction of Advantage. The Journal of Technology Transfer 31 (1), pp. $5^{-15}$.

Daellenbach, U., and Davenport, S. (2013). Making a Virtual Research Centre "real": How Social Capital Formation Facilitates Organizational Identity Construction in a Virtual Organization. In: Johnson, C.D., ed. Social Capital: Theory, Measurements and Outcomes. New York: Nova Science Publishers, pp. 363-388. 
Davidsson, P., and Honig, B.L. (2003). The Role of Social and Human Capital among Nascent Entrepreneurs. Journal of Business Venturing 18 (3), pp. 301-331.

Dawson, P., and Daniel, L. (2010). Understanding Social Innovation. International Journal of Technology Management 51, pp. 9-21.

Dalziel, P., and Saunders, C. (2014). Wellbeing Economics: Future Directions for New Zealand.Wellington: Bridget Williams Books.

Deakin, M., and Leydesdorff, L. (2014). The Triple Helix Model of Smart Cities: A Neo-Evolutionary Perspective. In: Deakin, M. (ed.) Smart Cities: Governing, Modelling and Analysing the Transition. London and New York: Routledge, pp 134-149.

De Liso, N., and Metcalfe, J. (1996). On Technological Systems and Technological Paradigms: Some Recent Developments in the Understanding of Technological Change. In: Helmstädter, E., and Perlman, M., eds. Behavioral Norms, Technological Progress, and Economic Dynamics: Studies in Schumpeterian Economics. Ann Arbor: University of Michigan Press, pp. 71-95.

Drori, I., Honig, B., and Wright, M. (2009). Transnational Entrepreneurship: An Emergent Field of Study. Entrepreneurship Theory and Practice 33 (5), pp. 1001-1022.

Elo, M., and Freiling, J. (2015). Transnational Entrepreneurship: An Introduction to the Volume. American Journal of Entrepreneurship 8 (2).

Engel, T., and J. Knieling (2017). Soziale Innovation. Eine begriffliche Annäherung. In: Dorn, F.M., and Kratzer, A., eds. Governance for Sustainability Transitions: Herausforderungen und Veränderungsprozesse in Regionen gestalten. Dokonara 2015 - Internationales DoktorandInnenkolleg Nachhaltige Raumentwicklung. Innsbruck: Innsbruck University Press.

Etzkowitz, H. (1985). Toward a Humanist Perspective on Science and Technology. Humanity and Society 9 (4), pp. 364-370.

Etzkowitz, H. (1987). Environmentalism and Equity: Distributional Conflicts in Environmental Resource Policy. Science 235 (4791), pp. 914-915.

Etzkowitz, H. (2008). The Triple Helix: University-Industry-Government Innovation in Action. London and New York: Routledge, p. 31.

Etzkowitz, H. (2013). Silicon Valley: The Sustainability of an Innovation Region. Social Science Information $5^{2}(4)$, pp. 515-538.

Etzkowitz, H. (2015). Making a Humanities Town: Knowledge-Infused Clusters, Civic Entrepreneurship and Civil Society in Local Innovation Systems. Triple Helix 1. Available at: https://www.springerprofessional.de/en/triple-helix-1-2015/11901838. Accessed 18 August 2018.

Etzkowitz, H., and Steiber, A. (2019). Silicon Valley's Paradox of Success: A Katrina Effect. In: Nourani, C.F., ed. Computing Predictive Analytics, Business Intelligence, and Economics: Modeling Techniques with Start-ups and Incubators. Abingdon: Routledge, p. 155 . 
Etzkowitz, H. and Leydesdorff, L. (2000). The Dynamics of Innovation: From National Systems and "Mode 2" to a Triple Helix of University-Industry-Government Relations. Research Policy 29 (2), pp. 109-123.

Fadaee, S. and Schindler, S. (2014). The Occupy Movement and the Politics of Vulnerability. Globalizations 11 (6), pp. 777-779.

Fagan, M.B. (2009). Fleck and the Social Constitution of Scientific Objectivity. Studies in History and Philosophy of Science Part C: Studies in History and Philosophy of Biological and Biomedical Sciences 40 (4), pp. 272-285.

Feldman, M., and Lowe, N. (2018). Policy and Collective Action in Place. Cambridge Journal of Regions, Economy and Society 11 (2), pp. 335-351.

Fischer, F. (2012). Participatory Governance: From Theory To Practice. In: LeviFaur, D., ed. The Oxford Handbook of Governance. Oxford: Oxford University Press.

Florida, F., Mellander, C. and Rentfrow, P.F. (2013). The Happiness of Cities. Regional Studies 47 (4), pp. 613-627.

Florin, P. (1990). An Introduction to Citizen Participation, Voluntary Organizations, and Community Development: Insights from Empowerment through Research. American Journal of Community Psychology 18 (1), p. 14.

Folke, C., Hahn, T., Olsson, P., and Norberg, J. (2005). Adaptive Governance of Social-Ecological Systems. Annual Review of Environment and Resources 15 (30), pp. 441- 473 .

Foray, D., David, P.A., and Hall, B.H. (2011). Smart Specialization. From Academic Idea to Political Instrument, the Surprising Career of "A Concept and the Difficulties Involved in its Implementation". MTEI-Working Paper 2011-001.

Fukuyama, F. (2011) The Origins of Political Order: From Prehuman Times to the French Revolution. New York: Farrar, Straus and Giroux.

Gebhardt, C. (1997). Die Regionalisierung von Innovationsprozessen in der Informationstechnologie. Deutscher Universitätsverlag.

Gebhardt, C. (2013) The Making of Plasma Medicine: Strategy Driven Clusters and the Emerging Roles of Cluster Management and Government Supervision. Journal of Technology Transfer 38 (4), pp. 401-414.

Gebhardt, C. (2017). Humans in the Loop: The Clash of Concepts in Digital Sustainability in Smart Cities. In: Osburg, T., and Lohrmann, C., eds. Sustainability in a Digital World. Springer, Cham, pp. 85-93.

Gebhardt, C. and Pohlmann, M.C. (2013). Managing the Organisation 2.o: Entrepreneurial Spirit and General Management Competences as Early Indicators for Cluster Success and Sustainable Regional Development - Findings from the German Entrepreneurial Regions Programme. Journal of High Technology Management Research 24 (2), pp. 153-16o. 
Geels, F.W. (2002). Technological Transitions as Evolutionary Reconfiguration Processes: A Multi-Level Perspective and a Case-Study. Research Policy 31 (8-9), pp. 1257-1274.

Geels, F. W., \& Schot, J. (2007). Typology of sociotechnical transition pathways. Research Policy, 36(3), 399-417.

Giddens, A. (1990) The Consequences of Modernity. Cambridge: Polity Press.

Gong, H., and Hassink, R. (2017). Exploring the Clustering of Creative Industries. European Planning Studies 25 (4), pp. 583-6oo.

Grandori, A. (1997). Governance Structures, Coordination Mechanisms and Cognitive Model.Journal of Management and Governance 1 (1), pp. 29-47.

Granovetter, M.S. (1977). The Strength of Weak Ties. American Journal of Sociology 78 (6), pp. $1360-1380$.

Granovetter, M.S. (1985). Economic Action and Social Structure: The Problem of Embeddedness. American Journal of Sociology 91 (3), pp. 481-510.

Grint, K. (2010). Wicked Problems and Clumsy Solutions: The Role of Leadership. In: Brooks, S., Grint, K., eds. The New Public Leadership Challenge. Palgrave Macmillan: Basingstoke.

Hansen, T., and Coenen, L. (2015). The Geography of Sustainability Transitions: Review, Synthesis and Reflections on an Emergent Research Field. Environmental Innovation and Societal Dutch History 17, pp. 92-109.

Hardin, G. (1968). The Tragedy of the Commons. Science 162 (3859), pp. 1243-1248.

Hassink, R., Isaksen, A., and Trippl, M. (2018). Towards a Comprehensive Understanding of New Regional Industrial Path Development. Working Paper PEGIS, Papers in Economic Geography and Innovation Studies.

Havermans, D., Appel-Meulenbroek, R., and Smeets, J. (2008). Rebranding the City The Case of Eindhoven. Available at: http://medewerkers.tudelft.nl/fileadmin/ Faculteit/BK/Actueel/Symposia_en_congressen/CRE_2008/Papers/doc/Papero7_ Havermans.pdf. Accessed 20 August 2018.

Head, B.W. (2008). Wicked Problems in Public Policy. Public Policy 3 (2), pp. 101-118.

Head, B.W., and Alford, J. (2015). Wicked Problems: Implications for Public Policy and Management. Administration \& Society 47 (6), pp. 711-739.

Hohn, H.W., and Schimank, U. (1990). Konflikte und Gleichgewichte im Forschungssystem: Akteurkonstellationen und Entwicklungspfade in der staatlich finanzierten außeruniversitären Forschung. Campus Verlag.

Kanter, R.M. (1998). From Spare Change to Real Change: The Social Sector as Beta Site for Business Innovation. Harvard Business Review 77, pp. 122-132.

Kaufmann, A. and Toedtling, F. (2001). Science-Industry Interaction in the Process of Innovation: The Importance of Boundary-Crossing between Systems.Research Policy 30 (5), pp. 791-804. 
Kibert, C.J. (2016). Sustainable Construction: Green Building Design and Delivery. Hoboken, NJ: John Wiley \& Sons.

Krohn, W., and Küppers, G. (1992). Emergenz: Die Entstehung von Ordnung. Organisation und Bedeutung. Suhrkamp: Frankfurt am Main.

Kuhlmann, S., and Shapira, P. (2006). How is Innovation Influenced by Science and Technology Policy Governance? Transatlantic Comparisons. In: Hage, J., and Meeus, M., eds. Innovation, Science and Institutional Change: A Research Handbook. New York: Oxford University Press, pp. 232-255.

Lewin, K. (1947). Frontiers in Group Dynamics: Concept, Method and Reality in Social Science; Social Equilibria and Social Change. Human Relations 1 (1), pp. 5-41.

Leydesdorff, L., and Deakin, M. (2013). The Triple Helix Model of Smart Cities: A Neo Evolutionary Perspective. In: Deakin, M., ed. Smart Cities. Abingdon: Routledge, pp. 146-161.

Light, P.C. (2006). Reshaping Social Entrepreneurship. Stanford Social Innovation Review 4 (3), pp. 47-51.

Lovan, W.R., Murray, M. and Ron Shaffer, R. (2017). Participatory Governance: Planning, Conflict Mediation and Public Decision-Making in Civil Society. Abingdon: Routledge.

Lowe, N.J. and Wolf-Powers, L. (2018). Who Works in a Working Region? Inclusive Innovation in the New Manufacturing Economy. Regional Studies $5^{2}$ (6), pp. 828-839.

Lundstrom, A., Zhou, C., von Friedrichs, Y., and Sundin, E., eds. (2014). Social Entrepreneurship: Leveraging, Economic, Political and Social Dimensions. Heidelberg: Springer.

MacCallum, D., ed. (2009). Social Innovation and Territorial Development. Farnham: Ashgate.

Madsen, S., and Hansen, T. (2019). Cities and Climate Change - Examining Advantages and Challenges of Urban Climate Change Experiments. European Planning Studies 27 (2), pp. 282-299.

Martin, R. (2013). Differentiated Knowledge Bases and the Nature of Innovation Networks. European Planning Studies, 21, pp. 1418-1436.

Martin, R. (2014). Path Dependence and the Spatial Economy: A Key Concept in Retrospect and Prospect. In: Fischer M.M, and Nijkamp, P., eds. Handbook of Regional Science. Berlin: Springer, pp. 6o9-629.

Martin, R., and Sunley, P. (2006). Path Dependence and Regional Economic Evolution. Journal of Economic Geography, 6, pp. 395-437.

Martin, R., and Trippl M., eds. (2017). New Avenues for Regional Innovation Systems. Theoretical Advances, Empirical Cases and Policy Lessons. Cham: Springer, pp. 85-104. 
Martinez-Alier, J., Anguelovski, I., Bond, P., Del Bene, D., and Demaria, F. (2014). Between Activism and Science: Grassroots Concepts for Sustainability Coined by Environmental Justice Organizations.Journal of Political Ecology 21 (1). DoI: https://doi .org/10.2458/v21i1.21124.

Maassen, A. (2012). Heterogeneity of Lock-in and the Role of Strategic Technological Interventions in Urban Infrastructural Transformations. European Planning Studies 20 (3), pp. 441-46o.

Mieg, H., and Grafe, F.J. (2012). City Development under the Constraints of Complexity and Urban Governance: A Case Study on the Application of Systems Modelling and "Syntegration" to the City of Fürth. Journal of Urban Regeneration \& Renewal 6 (1), pp. 91-100.

Mieg, H.A., and Töpfer, K., eds. (2013). Institutional and Social Innovation for Sustainable Urban Development. Abingdon: Routledge.

Moulaert, F., Martinelli, F., González, S., and Swyngedouw, E. (2007). Introduction: Social Innovation and Governance in European Cities: Urban Development Between Path Dependency and Radical Innovation. European Urban and Regional Studies 14 (3), pp. 195-209.

Mora, L., Bolici, R., and Deakin, M. (2017). The First Two Decades of Smart-City Research: A Bibliometric Analysis.Journal of Urban Technology 24 (1), pp. 3-27.

Nauwelaers, C., Maguire, K., and Ajmone Marsan, G. (2013). The Case of the Top Technology Region/Eindhoven-Leuven-Aachen Triangle (TTR-ELAt) - Regions and Innovation: Collaborating Across Borders. OECD Regional Development, Working Papers, 2013/22. Paris: OECD Publishing.

Neumeier, S. (2012). Why do Social Innovations in Rural Development Matter and Should They be Considered More Seriously in Rural Development Research? Proposal for a Stronger Focus on Social Innovations in Rural Development Research. Sociologia Ruralis 52, pp. 48-69.

Osburg, Th and Schmidpeter, R., eds. (2013). Social Innovation - Solutions for a Sustainable Future, csR, Sustainability, Ethics \& Governance. Springer-Verlag Berlin Heidelberg.

Ostrom, E. (2000). Collective Action and the Evolution of Social Norms. The Journal of Economic Perspectives 14 (3), pp. 137-158.

Paasi, A. (2003). Region and Place: Regional Identity in Question. Progress in Human Geography 27 (4), pp. 475-485.

Patel, P.C. and Conklin, B. (2017). The Balancing Act: The Role of Transnational Habitus and Social Networks in Balancing Transnational Entrepreneurial Activities. Entrepreneurship Theory and Practice 33 (5), pp. 1045-1078.

Perrini, F., Vurro, C., and Costanzo, L.A. (2010). A Process-Based View of Social Entrepreneurship: From Opportunity Identification to Scaling-up Social Change 
in the Case of San Patrignano. Entrepreneurship \& Regional Development 22, pp. 515-534.

Pfiffner, M. (2001). Team Syntegrity, Der Kybernetische Weg zur Willensbildung in Organisationen. Malik on Management 5, pp. 75-94.

Powell, M.C., and Colin, M. (2008). Meaningful Citizen Engagement in Science and Technology: What Would it Really Take?Science Communication 30 (1), pp. 126-136.

Presutti, M., Boari, C., Fratocchi, Pret, L.T., Shaw, E. and Drakopoulou, S.D. (2007). Knowledge Acquisition and the Foreign Development of High-Tech Start-Ups: A Social Capital Approach.International Business Review 16 (1), pp. 23-46.

Pruthi, S. and Wright, M. (2017). Social Ties, Prior Experience and Venture Creation by Transnational Entrepreneurs. International Journal of Entrepreneurship and Small Business 19 (4), pp. 15-27.

Raven, R., Schot, J., and Berkhout, F. (2012). Breaking out of the National: Foundations for a Multi-Scalar Perspective of Socio-Technical Transitions. Working Paper 12/03. Eindhoven: Center for Innovation Studies.

Ritala, P., Agouridas, V., Assimakopoulos, D. and Gies, O. (2013). Value Creation and Capture Mechanisms in Innovation Ecosystems: A Comparative Case Study. International Journal of Technology Management 63 (3-4), pp. 244-267.

Roberts, N. (2000). Wicked Problems and Network Approaches to Resolution. International Public Management Review 1 (1), pp. 1-9.

Ross, A. and Heap, S.H. (1992). Understanding the Enterprise Culture: Themes in the Work of Mary Douglas. Edinburgh: Edinburgh University Press.

Russell, M.G., Huhtamäki, J., Still, K., et al. (2015). Relational Capital for Shared Vision in Innovation Ecosystems. Triple Helix 2: 8.

Sassen, S. (2003). The Participation of States and Citizens in Global Governance. Indiana Journal of Global Legal Studies 10 (1).

Saxenian, A. (1999). Silicon Valley's New Immigrant Entrepreneurs. San Francisco, CA: Public Policy Institute of California.

Saxenian, A. (2002) Transnational communities and the evolution of global production networks: The cases of Taiwan, China and India. Industry and Innovation 9/3: 183-202.

Saxenian, A. (2007). The New Argonauts: Regional Advantage in a Global Economy. Cambridge, MA: Harvard University Press.

Saxenian, A. and Hsu, J.Y. (2001). The Silicon Valley-Hsinchu Connection: Technical Communities and Industrial Upgrading. Industrial and Corporate Change 10 (4), pp. 893-920.

Scharpf, F.W. (2018). Games Real Actors Play: Actor-Centered Institutionalism in Policy Research. Abingdon: Routledge. 
Schein, E.H. (1968). Personal Change through Interpersonal Relationships. In: Bennis, W.G., Schein, E.H., Steele, F.I. and Berlew, D.E., eds. Interpersonal Dynamics. Dorsey Press: Homewood, IL.

Schein, E.H. (1993). On Dialogue, Culture, and Organizational Learning. Organizational Dynamics Winter, pp. 40-51.

Schneidewind, U. (2014). Urbane Reallabore: ein Blick in die aktuelle Forschungswerkstatt.

Scholz, T., Koehler, C., and Evans, G.R. (2009). Do Effective Meetings Determine Progress in Research?Health Services Management Research 22 (4), pp. 197-200.

Senge, P. (1990). The Fifth Discipline. New York: Doubleday.

Shi, L., Chu, E., Anguelovski, I., Aylett, A., Debats, J., Goh, K., ... and Roberts, J.T. (2016). Roadmap Towards Justice in Urban Climate Adaptation Research. Nature Climate Change 6 (2), p. 131.

Sydow, J. (1992). Strategische Netzwerke. Evolution und Organisation. Wiedbaden: Springer Gabler.

Termeer, C.J., Dewulf, A., Breeman, G., and Stiller, S.J. (2015). Governance Capabilities for Dealing Wisely with Wicked Problems. Administration \& Society 47 (6), pp. 680-710.

Therkildsen, H.P., Hansen, C.J., and Lorentzen, A. (2009). The Experience Economy and the Transformation of Urban Governance and Planning. European Planning Studies 17 (6), pp. 925-941.

Urbano, D., Toledano, N., and Sorian, D.R. (2010). Analyzing Social Entrepreneurship from an Institutional Perspective: Evidence from Spain. Journal of Social Entrepreneurship 1, pp. 54-69.

Viitanen, J., and Kingston, R. (2014). Smart Cities and Green Growth: Outsourcing Democratic and Environmental Resilience to the Global Technology Sector. Environment and Planning A 46 (4), pp. 803-819.

Wagner, C.S., and Leydesdorff, L. (2005). Network Structure, Self-Organization, and the Growth of International Collaboration in Science. Research Policy 34 (10), pp. $1608-1618$.

Walk, H. (2008). Partizipative Governance: Beteiligungsformen und Beteiligungsrechte im Mehrebenensystem der Klimapolitik. Wiesbaden: Springer VS.

Wanner, M., Hilger, A., Westerkowski, J., Rose, M., Stelzer, F., and Schäpke, N. (2018). Towards a Cyclical Concept of Real-World Laboratories: A Transdisciplinary Research Practice for Sustainability Transitions. disP-The Planning Review 54 (2), pp. 94-114.

Weick, K.E. (1995). Sensemaking in Organizations: Foundations for Organizational Science. Thousand Oaks, CA: Sage. 


\section{Appendix 1}

Syntegration ${ }^{\oplus}$ participants: S: Science; A: Academia; I: Industry; G: Government; S: Social initiative/Other

Evening guests: Mayor of Helmond, representatives of other neighbouring cities (Gemeente Breda, Gemeente Eindhoven, Gemeente Tilburg, Gemeente Den Bosch, Media and King's Commissioner of North Brabant).

APPENDIX 1 Syntegration ${ }^{\circ}$ workshop: participants, listed by affiliation (background:

S: Science; G: Government; I: Industry; C: Citizen / non for profit).

S: Fontys Venlo University of Applied Sciences

G/Province Level: Provincie Noord-Brabant

G/city level. 3 members of Gemeente Helmond

I/Building. Wolters Vastgoed

I: Business Development Manager

C: Urban farming Initiatiefnemer Buurtmoestuin, expert stadslandbouw

S: Marketing Chess Wise, IoT Patform Building Environment

I: Manager Zuid Nederland Eneco Holding, Energy as a Service

S: Oprichter en ingenieur, locale interest group

G/ I: Public Affairs en Investor Relations, NFP inclusive society

S: Research Assistant at Fraunhofer IAO

S: Mobility Innovation

C: Fysiotherapeut Brandevoort

G: Programma Manager Duurzame en Gezonde Stad

G/ S: Advice and management o.a. Triangulum

G: Program Manager BSD

G: Program Manager Wonen

G: Program Manager ABS

G: Program Manager Sociale Stad

C: Intercultural Business Communication

I: Commercial director

I: Conceptontwikkeling innovatieve bouwoplossingen, real estate dev.

I: Bewoner, IoT Platform Brandevoort, cloud control, applied analytics

S: Senior strateeg KPN en hoogleraar network architecture and services TU Delft

G: Interim Beleidsadviseur Energy \& Cleantech Provincie Noord-Brabant

A: Directielid vocational schools

S: Advocaat, Specialist IT-Law

G: Innovation Manager, Energy 
G: Beleidsadviseur Energy and Clean Technology

I: Directeur Pariculieren vestiging Helmond

I: Community software voor woningbowuprojecten, co-founder technology and services to connect communities (Apps)

S: Initiatiefnemer Duurzamer Helmond, de Weggeefhouk, bewoner Brandevoort, sharing economy

S: Innovation Hub Lead

S/A Student-assistant program Kijk op Brabant: concurrentiepositie Brabant in

Europa (Masterclass Caring Building)

S: Onderzoeker Law, allignment open data and privacy

S: Programma Manager Sociale Innovatie

S: Burgerparticipatie/citizen perspective/trust/values social dynamics/resilience

S: Directeur Tranzo, wetenschappelijk centrum voor zorg en welzijn

S: Chair Information Systems Department Built Environment

S: Medewerker Onderwijsontwikkeling faculteit Bouwkunde

S: Hoogleraar Building Sustainability, bestuurlijk verantwoordelijk faculteit bouwkunde

S: Project leader TU/e Smart Cities Project

S: Medewerker Faculteit Industrial Engineering and Innovation Sciences

G/S: Coordinator Water Management 


\section{Author Query:}

AQ1: Please provide the Figure Caption. 